\title{
FIRST RECORD OF ISOPACHES DECOLORANS (MARCHANTIOPHYTA, LOPHOZIACEAE) FROM XIZANG, CHINA
}

\author{
Li-Na Zhang, XiA-FAng Cheng \& RUI-Liang ZHU
}

\begin{abstract}
Isopaches decolorans (Limpr.) H. Buch, a rare, arctic and alpine species with remarkably disjunct distribution of the northern hemisphere, is found for the first time in Xizang (Tibet), China. In China it is a poorly known liverwort previously reported only from Sichuan and Yunnan. The colorful illustrations and detailed description of $I$. decolorans are provided, and SEM observation of elaters and spores is presented for the first time.
\end{abstract}

Key words: Anastrophyllaceae, Isopaches, Lophoziaceae, Scapaniaceae, spore, Tibet

Li-Na Zhang, Department of Biology, School of Life Science, East China Normal University, 500 Dongchuan Road, Shanghai 200241, China; Department of Bioengineering, School of materials and Chemical Engineering, Hainan University, 58 Renmin Road, Haikou 570228, Hainan, China; e-mail: zhlina99@gmail.com

Xia-Fang Cheng, Department of Biology, School of Life Science, East China Normal University, 500 Dongchuan Road, Shanghai 200241, China; e-mail: xfcheng@bio.ecnu.edu.cn

Rui-Liang Zhu, Department of Biology, School of Life Science, East China Normal University, 500 Dongchuan Road, Shanghai 200241,China; e-mail: lejeunea@163.com

\section{INTRODUCTION}

Isopaches $\mathrm{H}$. Buch, an oligotypic genus, was established by Buch (1933). Schuster (1951) treated Isopaches as a subgenus of Lophozia (Dumort.) Dumort., but molecular evidences in recent years revealed that Isopaches should be recognized at generic level (De Roo et al. 2007; CrandallStotler et al. 2009; Vilnet et al. 2010). Isopaches contains four species. One species, I. bicrenatus (Schmid. ex Hoffm.) H. Buch, is very widespread in the boreal and temperate regions of the northern hemisphere. Two other species, I. pumicicola (Berggr.) Bakalin is known from New Zealand (Bakalin 2008) and I. alboviridis (R. M. Schust.) Schljakov mainly in West Greenland, Alaska and Siberia (Schuster 1969; Potemkin 1990, 1993). The fourth, I. decolorans (Limpr.) H. Buch, is reported as a rare and highly disjunct species which is known from Central Europe, Scandinavia, west and east Siberia, Bhutan, Nepal, tropical Africa and British Columbia (e.g., Müller 1951-1958; Potemkin 1990, 1993; Schuster 1995; Váňa 2004; Long 2005). In China I. decolorans is still poorly known. The first report for this species in China was made by Long (2005 as Lophozia decolorans) who found it in Deqin Co., North-west Yunnan. During recent expedition to China, Long (2011 as $L$. decolorans) reported its occurrence in the alpine area in south-west Sichuan. In July 2012 the senior author of this paper found fertile populations in east Xizang. Although I. decolorans spreads in some regions of Asia, no full illustrations and detailed description based on Asian samples are available except the only description based on specimens from Yamal Peninsula (Potemkin 1990). This paper aims to report the new locality, provide a colorful illustration and detailed description, present SEM observation for the first time, and discuss the morphological variations.

\section{MATERIAL AND METHODS}

The samples were collected in Linzhi Co., Xizang, China on 28 July 2012. Materials for SEM studies were without chemical treatment, mounted on mental stubs, and then coated with gold. SEM micrographs were made with a Hitachi S4800 scanning electron microscope. The 
cross sections of the stem and capsule were carried out by cryostat microtome (Leica CM1900). The samples were embedded in compound OCT (Tissue-Tek OCT compound 4583), frozen at minus 20 degrees Celsius and cryo-sectioned. The stems were stained by neutral red before embedded in OCT. Samples for LM studies were examined under a light microscope (Zeiss Imager A1 or Olympus BX 43). The photos were taken with Spot Flex digital camera and Olympus DP 71 digital camera. The field pictures were photographed with a digital camera (Canon G11).

\section{DESCRIPTION}

Isopaches decolorans (Limpr.) H. Buch

Figs 1 \& 2

Mem. Soc. F. Fl. Fenn. 8: 288. 1932. झ Jungermannia decolorans Limpr., Jahresb. Schles. Gesell. Vaterl. Kult. 57: 116. 1880. $\equiv$ Lophozia decolorans (Limpr.) Steph., Sp. Hepat. 2: 147. 1902.

Plants yellowish green, more or less reddish when old, creeping, closely attached or semiimmersed to substrate. Shoots very compact, silkworm-shaped, julaceous, $0.8-3.0 \mathrm{~mm}$ long, $0.60-0.75 \mathrm{~mm}$ wide. Stem simple to scarcely branched, 8-10(-11) cells high, cross-section subelliptical, 263-366 × 171-283 $\mu \mathrm{m}$; medulla homogeneous with large, somewhat thick-walled, nearly round cells; dorsal cortical cells similar to medullary, while ventral cortical cells slightly to scarcely smaller, and walls of ventral cortical somewhat thicker than the medullary and dorsal layer. Leaves erect, sub-transversely inserted, laterally oppressed to the stem, densely imbricate, more or less decolorate at distal part, broadly orbicular to reniform, $0.55-0.67 \mathrm{~mm}$ long, $0.58-0.85 \mathrm{~mm}$ wide, subsymmetrically bilobed to $0.1-0.2$ their length, occasionally very shallowly 3-lobed, lobes broadly triangular, sinus widely V-shaped to crescentic, margin entire. Leaf cells subquadrate to rectangular, thick-walled, trigones indistinct, cuticle smooth, marginal cells 17-30 $\times 12-23 \mu \mathrm{m}$, median cells $20-38 \times 15-25 \mu \mathrm{m}$, basal cells $25-45 \times 15-33 \mu \mathrm{m}$; oil bodies grayish, spherical to ovoid, granular, 3-9 per cell, 5.6-8.2 $\times 1.8-5.6 \mu \mathrm{m}$, often absent in discoloured portion. Underleaves absent. Rhizoids numerous, long, colorless to light brown, densely spreading along ventral surface of stem.

Dioicous (male plants not found). Gynoecia terminal from short, unbranched shoots. Bracts in 3 pairs, closely compact together, strongly concave or cupped, usually decolorate toward apex, broadly ovoid-subrotund to slightly reniform, larger than leaves, 0.54-1.29 mm long, 0.67-1.77 mm wide; irregularly 2-3-lobed, lateral margins usually entire, rarely weakly dentate, apical margin irregularly toothed often ending in 1-2(-3)-celled apiculus apically. Perianth half-exserted, shortly cylindrical, usually decolorate especially in the upper portion, $1.6-1.8 \mathrm{~mm}$ long, $0.7-0.8 \mathrm{~mm}$ wide at middle, bearing 5 smooth keels variable in both shape and size, mouth apex nearly truncate, margin usually scattered crenulate to $1(-2)$-celled toothed. Seta $2.5-5.5 \mathrm{~mm}$ long, 5-7 cells $(247-302 \mu \mathrm{m})$ in diameter, in transverse section with 16 external cells and ca. 10 inner cells. Capsule ovoid, brownish black, 735-848 × 604-673 $\mu \mathrm{m}$, dehiscent into 4 equal, symmetrical, nearly oblonglanceolate valves separated from apex down to base, capsule wall 2-stratose, cells of outer layer larger than those of inner layer, outer and inner layer both with incomplete semi-annular bands and vestigial nodular thickenings; elaters bispiral, brown, filiform, rarely branched, attenuate to both ends, 107-314 $\mu \mathrm{m}$ long, 7.7-10.8 $\mu \mathrm{m}$ wide, spiral band of thickenings $2.7-3.1 \mu \mathrm{m}$ wide. Spores redbrown, spherical, 13-23 $\mu \mathrm{m}$ in diameter, surface densely corrugate with irregular, often short to long and branching ridges, ridges nearly smooth, raised at nodes to truncate processes on top, spaces somewhat deep, little wider than ridges. Asexual reproductive organs not seen.

Specimen eXamined: CHINA. Xizang, Linzhi Co., Sejilashan, mountain pass, $29^{\circ} 36^{\prime} 38.77^{\prime \prime} \mathrm{N}$, 94³9'06.92"E, on soil, 4720 m, 28 July 2012, RuiLiang Zhu 20120728-9 (HSNU).

\section{DISCUSSION}

MORPHOLOGY

Most authors (e.g., Schuster 1995; Boudier \& Skrzypczak 2002; Váňa 2004; Oyesiku 2008) 

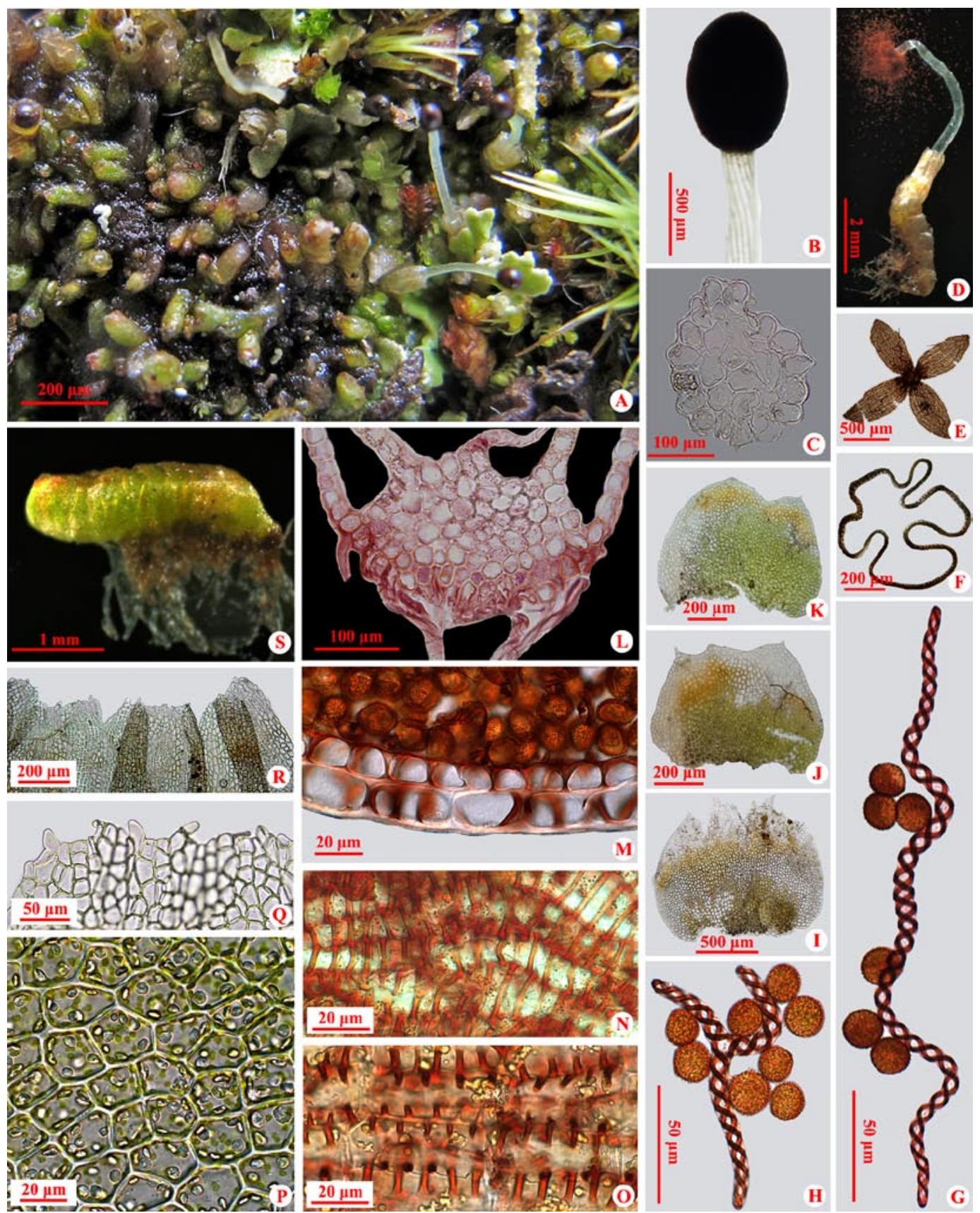

Fig. 1. Isopaches decolorans (Limpr.) H. Buch. A - Field plants on soil in Linzhi Co., Xizang; B - capsule with part of seta; $\mathrm{C}$ - transverse section of seta, $\mathrm{D}$ - female shoot bearing mature sporophyte with dehiscent capsule, releasing spores and elaters, $\mathrm{E}$ - capsule dehiscent into four valves, $\mathrm{F}$ - transverse section of perianth, showing five keels, $\mathrm{G}$ - elater and spores, $\mathrm{H}$ - branched elater and spores, I - female bract, J \& K - leaves, $\mathrm{L}$ - transverse section of stem and leaf-base, $\mathrm{M}$ - sector of transverse section of capsule wall, $\mathrm{N}$ - cells of inner layer of capsule, $\mathrm{O}$ - cells of epidermal layer of capsule, $\mathrm{P}$ - median cells of leaf showing oil bodies, Q \& R - part of perianth mouth, S - sterile shoot, lateral aspect. All from R.-L. Zhu 20120728-9 (HSNU). 

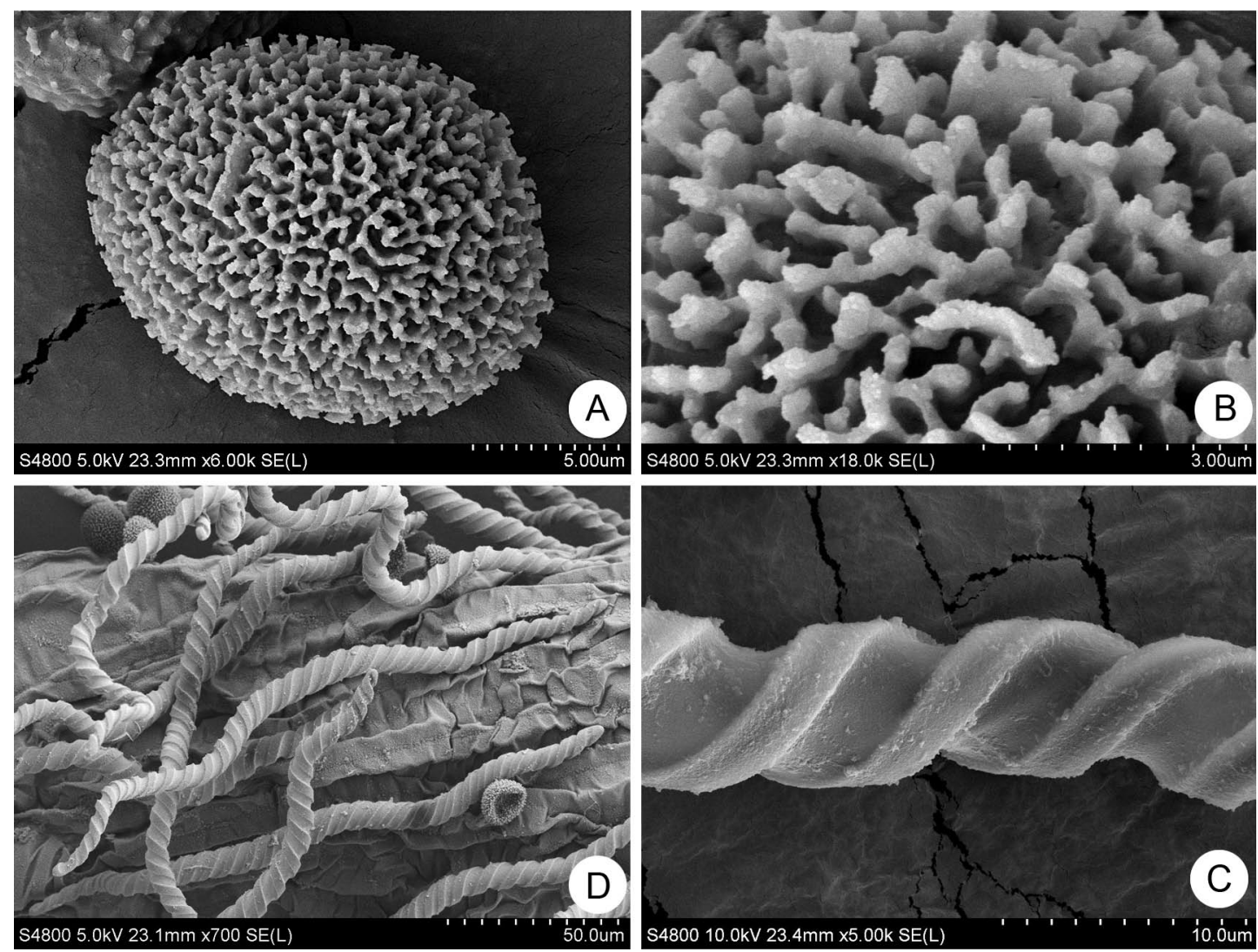

Fig. 2. SEM micrographs of Isopaches decolorans (Limpr.) H. Buch. A \& B - spore morphology and ornamentation, C \& D elater morphology and spiral band of thickenings. All from R.-L. Zhu 20120728-9 (HSNU).

reported that Isopaches decolorans was dioecious, while Potemkin (1993) noted that 'sex distribution is not constant in arctic populations of Isopaches species', I. decolorans in Yamal Peninsula, west Siberian arctic, is paroecious. In Xizang samples, we have neither found antheridia below the perianth, even nor found androecia (Fig. 1A \& D). The local $I$. decolorans seems to be dioicous.

The leaves of $I$. decolorans are usually bilobed, but the sinus was reported to be different in width or depth. In the American plant the leaf sinus is $0.10-0.15$ leaf length, $0.20-0.45$ leaf width (Schuster 1995). In the plant from Mt. Kenya, Africa (Chuah-Petiot 1995), it is bilobed to $c a 1 / 3$ its length, or shallow lobes 'not widely separate' from Uganda (Váňa 2004). In the Chinese samples of the present collection leaves are occasionally 3-lobed, and have widely V-shaped to widely crescentic sinus, $0.30-0.47$ leaf width and $0.09-0.17$ leaf length (Fig. $1 \mathrm{~J} \& \mathrm{~K}$ ).

The female bracts in the Xizang collection are broadly ovoid-subrotund to slightly reniform in shape, the widest nearly in the middle, and apex slightly contracted, irregularly 2-3-lobed, apical margin irregularly toothed (Fig. 1I). It differs from American plant in which the widest part is in basal third, distal part strongly contracted into two, almost juxtaposed lobes and the margin appears entire (Schuster 1995).

The perianth is somewhat different from the former reports. Müller (1905-1916) recorded that the perianth was entire and crenulate, Schuster (1995) stated the perianth mouth was variable in the degree of dentition, Potemkin (1993) noted 
that the perianth mouth was 'shortly ciliate, cilia 1-2(3)-celled', and 'crénelée-dentée' in French specimens (Boudier \& Skrzypczak 2002). Our observation shows that mouth apices are nearly truncate with 1-celled crenulate to 1(-2)-celled toothed margin (Fig. 1Q \& R), which are very closely to the description of African plant (Váňa 2004).

The SEM morphology of elaters and spores of I. decolorans is reported for the first time in this paper (Fig. 2). The elater is bispiral (Fig. 1G, 2C $\&$ D), and sometimes bifurcate (Fig. 1H). Spore sexine surface has corrugate and branching ridges with processes on top (Fig. 2A \& B), the ridges and processes are thinner than the processes of $I$. bicrenatus spores. In I. bicrenatus surface processes of the spores are 'irregular pilum- or barculum-like' (Boros et al. 1993).

The gemmae of $I$. decolorans are intense to yellow reddish colored, usually 1-2-celled and 4-5 angled, shape variable from stellate (Arnell 1956) in European plants, quadrate or subquadrate from America and Africa (Schuster 1995; Váňa 2004), to irregularly polygonal, rectangular and triangular from Russia (Potemkin 1990, 1993), but in the Xizang population no gemmae are found.

\section{DISTRIBUTION}

Isopaches decolorans was known as a rare and local European alpine species previously in France, Swizerland, Austria, Norway (Müller 1905-1916, 1951-1958; and others), Italy (Aleffi et al. 2008), etc. Schuster (1995) reported it for western north America. I. decolorans has also been found from Asia and Africa continually in recent years. In Asia the first record of this species was made by Ladyzhenskaya and Zhukova (1971) who reported its occurrence in Tomponskii Region of Yakutia, then Schljakov (1974), Potemkin (1990, 1993), Schuster and Konstantinova (1996), Bakalin (2005), Oyesiku (2008), and Potemkin and Sofronova (2009) recorded it for Russia mainly covering Siberia and Caucasus. In addition to the above distributions in Asia it is mainly reported for Himalayan region including Bhutan (Long 1979), Nepal, India (Sikkim), China (Sichuan, Yunnan) (Long 2005, 2011). In Africa, I. decolorans is lo- cated in Cameroon, Tanzania (Ván̆a 1982; Bizot et al. 1985), D.R. Congo (Nyiragongo) (Müller 1995), Uganda (Mbale) (O'Shea et al. 2003) and Equatorial Guinea (Bioko) (Müller 2006). The species spreads over equatorial Africa and deeply into the tropics, which indicated the distribution of I. decolorans is not confined in Europe alpine or arctic region, and maybe in more temperate and tropical alpine areas. It is inclined to be overlooked with small size, and this might result in rare reports in these areas previously.

So far Isopaches decolorans is the unique species of Isopaches found in China. Long (2005) first reported I. decolorans from Yunnan Province as a new hepatic record to China, and suggested that ' $L$. decolorans (=I. decolorans) may be a more widespread and locally abundant species in the East Himalaya and possibly also in Western China, than in other parts of range'. Six years later he reported I. decolorans for south-west Sichuan (Long 2011). The present record in Linzhi, Xizang is the third locality of this species in China and it is the first report for this region.

ACKNOWLEDGEMENTS. This research was sponsored by the National Natural Science Foundation of China (nos. 31170190, 30825004), the Special Program for the National Basic Work of the Ministry of Science and Technology, China (No. 2012FY110600). We also thank Professor Jiří Váňa for various help.

\section{REFERENCES}

Aleffi M., TACChi R. \& Cortini Pedrotti C. 2008. Checklist of the hornworts, liverworts and mosses of Italy. Bocconea 22: 1-255.

ARNELL S. 1956. Illustrated moss flora of Fennoscandia. I. Hepaticae. 1-308. Gleerup, Lund.

BAKALIN V. A. 2005. New data on distribution of liverworts on Kamchatka Peninsula (North-West Pacific, Russia). Arctoa 14: 155-162.

BAKALIN V. A. 2008. New data on distribution and taxonomy of some species in Lophoziaceae (Hepaticae). Arctoa 17: 161-164.

Bizot M., Pócs T. \& SHARP A. J. 1985. Results of a bryogeographical expedition to East Africa in 1968, III. Bryologist 88: $135-142$.

Boros Á., JÁRAI-KomLódi M., Tóth Z. \& NiLSSON S. 1993. 
An atlas of recent European bryophyte spores. 1-321. Scientia Publishing, Budapest.

Boudier P. \& SKrzypCZAK R. 2002. Au sujet de deux hépatiques «oubliées» de la bryoflore française: Lophozia decolorans (Limpr.) Steph. (Lophoziaceae, Marchantiophyta) et Apomarsupella revoluta (Nees) R. M. Schust. (Gymnomitriaceae, Marchantiophyta). Cryptog. Bryol. 23: 41-49.

BUCH H. 1933. Vorarbeiten zu einer Lebermoosflora Fennoscandias. I. Ein Versuch zur Aufteilung der Gattungen Lophozia Dum. und Sphenolobus Steph. Mem. Soc. Fauna Fl. Fennica 8: 282-297.

Chuah-Petiot M. S. 1995. Western Mount Kenya bryophytes - III. J. E. Africa Nat. Hist. 84: 39-63.

Crandall-Stotler B., Stotler R. E. \& Long D. G. 2009. Phylogeny and classification of the Marchantiophyta. Edinburgh J. Bot. 66: 155-198.

De Roo R. T., Hedderson T. A. \& SÖDERström L. 2007. Molecular insights into the phylogeny of the leafy liverwort family Lophoziaceae Cavers. Taxon 56: 301-314.

LADYZHENSKAYA K. I. \& ZHUKOVA A. L. 1971. De species Isopaches decolorans (Limpr.) Buch (Hepaticae) pro flora URSS nova notula. Novosti Sist. Nizsh. Rast. 8: 310-314.

LoNG D. G. 1979. Hepaticae from Bhutan, East Himalaya. Lindbergia 5: 54-62.

Long D. G. 2005. Notes on Himalayan Hepaticae 2: New records and extensions of range for some Himalayan leafy liverworts. Cryptog. Bryol. 26: 97-107.

LONG D. G. 2011. Bryophyte exploration of South-west Sichuan, China. Field Bryology 103: 32-39.

MÜLLER F. 1995. Neue und bemerkenswerte Moosfunde aus Zaire. Trop. Bryol. 10: 81-90.

MÜLLER F. 2006. Bryophytes of Bioko (Equatorial Guinea), results of an excursion in 2002. Trop. Bryol. 27: 9-17.

MÜLLER K. 1905-1916. Die Lebermoose Deutschlands. In: L. Rabenhorst's Kryptogamen-Flora von Deutschland, Oesterreich und der Schweiz. Ed. 2nd. 6: 1-870. Verlag Von Eduard Kummer, Leipzig.

MÜLlER K. 1951-1958. Die Lebermoose Europas. In: L. Rabenhorst's Kryptogamen-Flora von Deutschland,
Oesterreich und der Schweiz. Ed. $3^{\text {rd }}$ 6: 1-1365. Akademische Verlagsgesellschaft, Leipzig.

O’SHEA B. J., WigGINTON M. J., BRUGGEMAN-NANNEGA M. A., Hedenäs L., Matcham H. W., Frahm J.-P., Porley R. D., Ellis L. T., WATling M. C., BATEs J. E. \& VÁŇA J. 2003. Bryophytes of Uganda, 6. New and additional records, 3 . Trop. Bryol. 24: 161-168.

OYESIKU O. O. 2008. Additions to the hepatic flora of the Russian part of the Caucasus. J. Bryol. 30: 306-308.

Potemkin A. D. 1990. Lophozia alboviridis and L. decolorans (Hepaticae) on the Yamal Peninsula. Bot. Zhurn. (Moscow \& Leningrad) 75: 1086-1092.

Potemkin A. D. 1993. The Hepaticae of the Yamal Peninsula, West Siberian Arctic. Arctoa 2: 57-101.

Potemkin A. D. \& Sofronova E. V. 2009. Liverworts and hornworts of Russia. 1: 1-367. Saint Petersburg, Yakutsk.

SchlJAKOV R. N. 1974. Aditamenta ad Bryofloram URSS. Novosti Sist. Nizsh. Rast. 11: 354-360.

SCHUSTER R. M. 1951. Notes on Nearctic Hepaticae III. A conspectus of the family Lophoziaceae, with a revision of the genera and subgenera. Amer. Midl. Naturalist 45: $1-117$.

SCHUSTER R. M. 1969. The Hepaticae and Anthocerotae of North America, east of the hundredth meridian. II: 1-1062. Columbia University Press, New York and London.

SCHUSTER R. M. 1995. Notes on Nearctic Hepaticae, XVII. Lophozia decolorans, new to North America and the subgenus Isopaches. Bryologist 98: 246-250.

Schuster R. M. \& Konstantinova N. A. 1996. Studies on the distribution of critical arctic/subarctic Hepaticae with special reference to taxa found in Russia. Lindbergia 21: 26-48.

VÁŇA J. 1982. Notes on some African hepatic genera 1-5. Folia Geobot. Phytotax. 17: 63-87.

VÁŇA J. 2004. Bryophyte flora of Uganda. 3. Lophoziaceae. J. Bryol. 26: 293-299.

Vilnet A. A., Konstantinova N. A. \& Troitsky A. V. 2010. Molecular insight on phylogeny and systematics of the Lophoziaceae, Scapaniaceae, Gymnomitriaceae and Jungermanniaceae. Arctoa 19: 31-50. 